\title{
The Effect of Service Quality, Price Perception, and Brand Image on Feeling Value, and Customer Satisfaction at Dian Husada Mojokerto Hospital
}

\author{
Indarwati, Ida Bagus Cempena, Ida Bagus Udayana Putra \\ Master of Management, Universitas Warmadewa \\ indarindur2@gmail.com; ib_cempena@untag-sby.ac.id; udayanap10@gmail.com
}

\begin{tabular}{|c|}
\hline Published: 19/03/2021 \\
\hline $\begin{array}{l}\text { How to cite (in APA style): } \\
\text { Indarwati, Cempena, I. B., Putra, I. B. U. (2021). The Effect of Service Quality, Price Perception, and Brand } \\
\text { Image on Feeling Value, and Customer Satisfaction at Dian Husada Mojokerto Hospital. Jurnal } \\
\text { Ekonomi dan Bisnis Jagaditha, } 8 \text { (1), 71-80. doi: https://doi.org/10.22225/jj.8.1.3123.71-80 }\end{array}$ \\
\hline
\end{tabular}

\begin{abstract}
This study aims to determine the effect of service quality, perceived brand image price and perceived value on consumer satisfaction at Dian Husada Hospital, Mojokerto. The hypothesis in this study is that there is a partial effect of service quality on price perceptions on perceived value and service quality. And there is a significant effect of perceived service quality, price, brand image and perceived value simultaneously affect customer satisfaction at Dian Husada Hospital in Mojokerto. The population used in this study were 100 consumers at Dian Husada Hospital Mojokerto. The data analysis technique used is validity test, reliability test, classical assumption test, descriptive analysis, multiple linear regression analysis, multiple determination analysis, correlation coefficient analysis. The hypothesis test used is the $\mathrm{F}$ test and $\mathrm{t}$ test. Based on the $\mathrm{t}$ test results of Path Sub-Structure 1, service quality, price perception and brand image has a partial effect on perceived value. Based on the results of the t test Sub-Structure 2, the perceived service quality of price and value has a partial effect on service quality and brand image has no partial effect on customer satisfaction; Based on the results of the study of the F-Test Sub-Structure 1, the Sig. $<0.05$ is $0.000<0.005$, so the variables of Service Quality, Price Perception, and Brand Image have a significant influence on the Perceived Value. And based on the results of the study of the F-Test Sub-Structure Path 2, the value of Sig. $<0.05$ is $0.000<0.005$, so that the variables of Service Quality, Price Perception, Brand Image.
\end{abstract}

Keywords: Service Quality, Price Perception, Brand Image, Perceived Value, Customer Satisfaction

\section{INTRODUCTION}

The primary need for society is wrong only one is problem Health. The main need that is emphasized here is to get health services in accordance with the wishes of the community. To get adequate health services the community must come to health service institutions, namely hospitals. Tjiptono \& Chandra (2016) states that "Service quality is the level of excellence expected and control over that level of excellence is to meet customer desires". Comprehensive health services are now one of the hospital functions to provide satisfaction to consumers or patients. According to Kotler \& Keller (2012), quality is the totality of features and characteristics of a product or service that affects its ability to satisfy stated needs. or implied.

Servant quality has a very close relationship with customer or patient satisfaction, for a company the quality provided will have a long-term impact if consumers are satisfied with the services provided. Satisfaction is a feeling of pleasure or disappointment for someone who appears after comparing the performance or results of a product which is thought about the performance or the expected results (Kotler \& Keller, 2012). For a long time, consumers who are satisfied with the services provided will automatically make consumers return to a particular service user or product.

According to (Lupiyoadi \& Hamdani, 2006), the dynamics that occur in the service 
sector can be seen from the development of various service industries such as banking, insurance, aviation, telecommunications, retail, tourism, and professional service companies such as accounting firms, consultants and lawyers. In addition, it can also be seen from the rise of non-profit organizations, such as NGOs, government agencies, hospitals and universities which have now increasingly realized the need to improve service orientation to consumers/customers.

Where service is an important element to realize the desires of consumers. If the consumer is satisfied, the consumer will show the possibility to return to using the same service. However, if the consumer is not satisfied, the consumer can move to a competitor's company, besides that, the possibility of consumers being able to tell their experience to others will actually be creates a bad image for the company in the eyes of consumers (Supriyanto \& Soesanto, 2012). Customer satisfaction has become a central concept so that in business and management discourse (Tjipto \& Chandra, 2005). Customers generally expect products in the form of goods or services that are consumed to be accepted and enjoyed. with good or satisfying service (Assauri, 2003).

In addition to service quality, there are several other factors that affect customer satisfaction such as the perception of prices offered by hospitals or a service company. Revenue or profit from a health service company is one of them from service rates. However, if viewed from a patient's point of view, price perception is indicator elements for consumers to use health services. In certain situations consumers also pay less attention to prices or tariffs because they are more concerned about safety and healing. But not a few consumers or patients also consider the costs that will be incurred for obtaining these health services.

Prices are all forms of monetary costs sacrificed by consumers to obtain, own, utilize a number of combinations of goods and services from a product (Hasan, 2002). Three general approaches in tariff setting according to (Philip Kotler, 1987) are: tariff setting. based on cost, pricing based on buyers' perceptions, and tariff setting based on competition.

According to Schnaars in (Tjipto \& Chandra, 2005), basically the goal of a business is to create satisfied customers. Good service quality will certainly create satisfaction with service users. In the end, good service quality can provide several benefits, including the establishment of a harmonious relationship between providers of goods and services and customers, providing a good basis for creating customer loyalty and forming a word of mouth recommendation that is beneficial for providers. services (Tjiptono et al, 2003).

Brand image in a health service installation is one of the factors that will also affect the perceived value and customer satisfaction. According to (Istijanto, 2005) that a company that has a good image or reputation will encourage consumers to buy products that are offered, heightens ability compete, encourage morale and increase customer satisfaction. In this case, a hospital that has a good brand image can generate consumer confidence to come to use these health services.

Dian Husada Hospital as one of the health service providers cannot be separated from the competition with other health service providers which is increasing day by day. Kotler (1995) states that many factors are considered for choosing, but one way to attract customers and win the competition is by providing services that are in accordance with.

\section{LITERATURE REVIEW}

Kotler \& Keller (2016) define marketing management as the art and science of selecting target markets and obtaining, retaining, and increasing the number of customers through the creation, delivery and communication of superior customer value. Armstrong \& Kotler (2015) explain that marketing management is analyzing, implementing, and supervising, programs that are intended to make exchanges with the intended market with a view to achieving organizational goals.

Ben M. Enis in (Alma, 2014) states that marketing management is a process to increase the efficiency and effectiveness of marketing activities carried out by individuals or by companies. In general it can be concluded that marketing management is an art and science to reach target markets, maintain, and develop customers in the company so that the company can carry out company activities effectively and efficiently in order to achieve organizational goals.

Service quality is the level of excellence expected and control over that level 
of excellence is to fulfill customer desires according to Tjiptono \& Chandra (2016). Tjiptono (2012) defines service quality as a measure of how good the level of service provided is in accordance with customer expectations. Hanif (2013) argues that service quality is the difference between reality and customer expectations for the subscriptions they receive or receive.

Dimensions of Service Quality according to Kotler in Tjiptono \& Chandra (2016) there are five dominant factors or determinants of quality customer desires that can provide satisfaction. Organizations that are not qualified in providing services will be left behind and run over in business competition. Therefore, the service quality of Dian Husada Hospital must always be improved so that it can compete fairly with other hospitals by always trying to provide better quality products, competitive prices, faster product delivery and better service than its competitors. Products with poor quality, high prices, slow product delivery and poor service delivery methods can cause dissatisfaction to customers who ultimately will not use the product in the future (Suprapto, 2001 in (Martianawati, 2009)).

According to (Kotler \& Keller, 2012) price is an amount of money value given to a product/service, or the amount of money that is exchanged by consumers for benefits received because they have used/used a product/service. Meanwhile, according to Tjiptono (2012) price is a monetary unit/other measure (including goods/services) that exchanged/given to get the rights to a good/service. According to Lovelock and Patterson in (Tjiptono, 2005), the general purpose of pricing is to support the overall marketing mix strategy.

Price is the amount of money charged for the product / service, or the amount of value that consumers exchange for the benefits of owning or using the product / service (Kotler \& Amstrong, 2001). Price is the only element of the marketing mix that provides income for the organization (Tjiptono, 2005). Kotler (2002) announced his theory which explains that company image is the consumer's response to the overall offer given by the company and is defined as a number of beliefs, ideas, and society impression on an organization.

Brand Image is a representation of the overall perception of a brand and is formed from information and past experiences with that brand. The image of the brand is related to attitudes in the form of beliefs and preferences for a brand. Consumers who have a positive image of a brand are more likely to make purchases (Setiadi, 2003). Image is a mental image or concept about something. Kotler \& Keller (2012) more broadly defines image as the sum of beliefs, images, and impressions that a person has on an object.

According to Zeithaml (1988), perceived value is the overall consumer assessment of the benefits of a product or service based on perceptions of what is received and what is given. This is interpreted on what is given as a sacrifice that must be done by the respondent and what is received as a perceived benefit from the product. If the benefits obtained are higher than the sacrifices that have to be paid, then the product or service has a high value.

Kotler (2006) states that perceived value is a form that underlies the perceived service quality. The value of perceived service quality is conceptualized as a result and exchange or customer sales between perceived quality and customer sacrifice in both financial and non-financial terms. Non-financial sacrifices such as time, physical or psychological effort. The results obtained and the difference in service quality and the sacrifices made by customers will have an impact on customer satisfaction.

Sweeney \& Soutar (2001) states that there are four main aspects to measure perceived value, namely: emotional value, namely the ability related to feelings or emotions caused by the use of a product or service; social value is the ability of a product or service to increase a good social image in society; the price value is the ability of a product or service obtained from a price that seems to have price efficiency; and quality value is the benefit resulting from the perceived quality and expected performance of the product.

According to Sweeney \& Soutar (2001), the value dimension consists of four main aspects as follows:

1. Emotional Value,

2. Social Value,

3. Quality Value,

4. Price / Value for Money,

Kotler \& Keller (2008) state that satisfaction is the feeling of pleasure or disappointment of a person after comparing the performance or perceived results compared 
with hope. If the reality is the same as what is expected then the service is satisfactory, on the other hand, if the reality is not suitable, it is not satisfactory. Meanwhile, according to (Lovelock \& Wirtz, 2011) marketing is basically about satisfying the needs and desires of consumers. Satisfaction equals meeting customer expectations for nothing less and nothing more. When service providers distribute a value over and above what we expect, we will feel delighted.

Customer satisfaction is a customer assessment of a product or service in terms of assessing whether the product or service has met customer needs and expectations (Zeithaml, Bitner, \& Gremler, 2010). As for (Tjiptono, 2008) states that: "customer satisfaction or dissatisfaction is the customer response to evolution of perceived discrepancies / disconfirmations between prior expectations (or other performance norms) and the actual perceived performance of the product after use. Satisfaction is a form of a person's feelings after gaining experience with service performance that has met expectations (Gerson, 2004).

From the literature review above, a conceptual framework can be presented as follows:

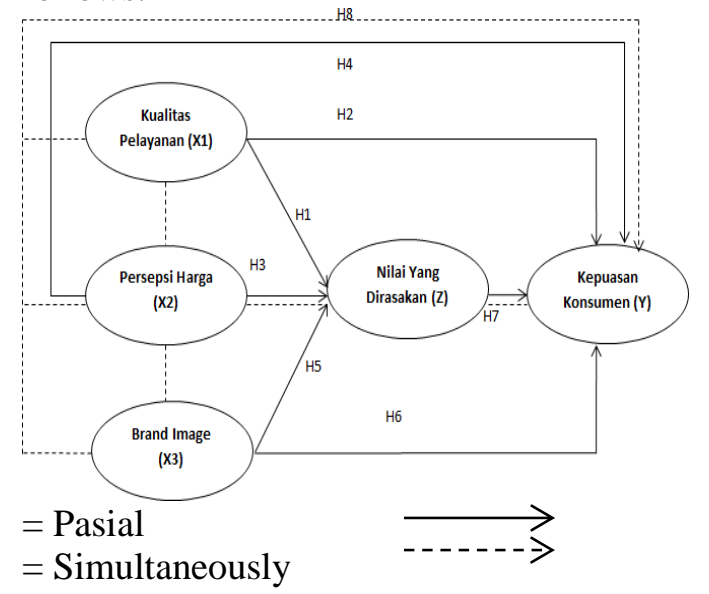

Based on the formulation of the problem, research objectives and descriptions that have been presented in the previous sections, the following research hypotheses can be formulated:

1. There is a significant effect of service quality on the perceived value of consumers (patients) at Dian Husada Hospital in Mojokerto

2. There is a significant effect of service quality on customer satisfaction
(Patient) Dian Husada Hospital in Mojokerto

3. There is a significant effect of perceived price on the perceived value of consumers (Patients) at Dian Husada Hospital in Mojokerto

4. There is a significant effect of perceived price on customer satisfaction (Patient) at Dian Husada Hospital in Mojokerto

5. There is a significant effect of Brand Image on the perceived value of consumers (Patients) at Dian Husada Hospital in Mojokerto

6. There is a significant effect of Brand Image on customer satisfaction (Patients) at Dian Husada Hospital in Mojokerto

7. There is a significant effect of perceived value on customer satisfaction (Patient) at Dian Husada Hospital in Mojokerto.

8. There is a significant influence on the perceived service quality of the price of Brand Image and the perceived value simultaneously influences customer satisfaction (Patient) at Dian Husada Hospital in Mojokerto.

\section{METHOD}

This research was conducted using a survey about influence quality services, price perception, brand image / brand image on perceived value and customer satisfaction at Dian Husada Hospital, Mojokerto. The type of data used in this study is included in quantitative data. The data analysis technique used is validity test, reliability test, classical assumption test, descriptive analysis, multiple linear regression analysis, multiple determination analysis, correlation coefficient analysis. The hypothesis test used is the F test and $t$ test.

\section{RESEARCH RESULTS AND DISCUSSION 4.1 Overview of Research Objects}

Dian Husada Hospital (RSDH) is a hospital managed by a foundation that has long experience in the field of health education in Indonesia, namely managing AKPER and Stikes Dian Husada since 2002. RSDH is located in a very strategic location with easy access on Jl. Raya Gemekan Sooko Mojokerto with a land area of approximately $20,000 \mathrm{~m} 2$. RSDH operates around June 2016. RSDH has a 
specialist polyclinic and general polyclinic. Has a bed capacity that is currently available around 100 pieces. The current physical facilities consist of 6 building blocks so that they are able to offer comprehensive health services through services diagnostic, curative, rehabilitation therapy, radiology, surgery and other medical services. With the motto "Serving with Kindness", we strive to provide the best possible service to patients for the convenience of patients. To provide the best possible service to patients, we have a guide in the form of 5 values core that is: Safety, Courteous, Sincere, Professional, Continuously always making improvements.

\subsection{Descriptions of Results Research Characteristics of Respondents by Age}

Characteristics of respondents by age can be described in Table 4.1:

Description of Respondent Age

\begin{tabular}{|c|c|c|}
\hline Age & Frequency & $\mathbf{\%}$ \\
\hline 17-27 years & 12 & 12 \\
\hline 23-28 years & 29 & 29 \\
\hline 34-49 years & 48 & 48 \\
\hline 50-60 years & 11 & 11 \\
\hline Total & $\mathbf{1 0 0}$ & $\mathbf{1 0 0}$ \\
\hline
\end{tabular}

Source: Appendix 5, processed data

Based on Table 4.1, it is known that the majority of respondents aged 34 - 49 years are 48 people (48\%), 23-28 years as many 29 people (29\%), 17-27 years old as many as 12 people $(12 \%)$ while the rest were respondents aged 50-60 years as many as 11 people $(11 \%)$.

\section{Characteristics of Respondents Based on Gender}

Characteristics of Respondents by

Gender Can be Described in:

Table 4.2: Description of the Gender of the Respondent

\begin{tabular}{|c|c|c|}
\hline Gender & Frequency & \% \\
\hline Man & 48 & 48 \\
\hline Women & 52 & 52 \\
\hline Total & $\mathbf{1 0 0}$ & $\mathbf{1 0 0}$ \\
\hline
\end{tabular}

Source: Appendix 5, processed data

Based on Table 4.2 , it is known that the majority of employees have male gender with a total of 48 people $(48 \%)$, while the rest are female respondents with a total of 52 people $(52 \%)$. This means that the majority of respondents are female.

\section{Characteristics of Respondents Based on Latest Education}

The characteristics of respondents based on their latest education can be described in the Table

\section{3: Respondent's Last Education}

\section{Description}

\begin{tabular}{|c|c|c|}
\hline $\begin{array}{c}\text { Education } \\
\text { Last One }\end{array}$ & Frequency & $\boldsymbol{\%}$ \\
\hline $\begin{array}{c}\text { Junior High } \\
\text { School }\end{array}$ & 25 & 25 \\
\hline Undergraduate & 74 & 74 \\
\hline Postgraduate & 1 & 1 \\
\hline Total & $\mathbf{1 0 0}$ & $\mathbf{1 0 0}$ \\
\hline
\end{tabular}

Source: Appendix 5, processed data

Based on Table 4.3, it can be seen that the majority of respondents have the latest high school education level with a total of 74 people (74\%), junior high school with a total of 25 people $(25 \%)$ while the respondent who has a bachelor's education level is only 1 person $(1 \%)$, this is It can be said that most of the respondents had a high school education level.

\section{Test Instrument (Test Validity and \\ Reliability) \\ Validity test}

Test validity is used to measure whether the statements in the questionnaire made can actually measure what we have measured (Ghozali \& Latan, 2012). If the results of the correlation between each question and the total score show significant results (significant $<0.05$ and correlation $>0.4$ ), then the question item is declared valid.

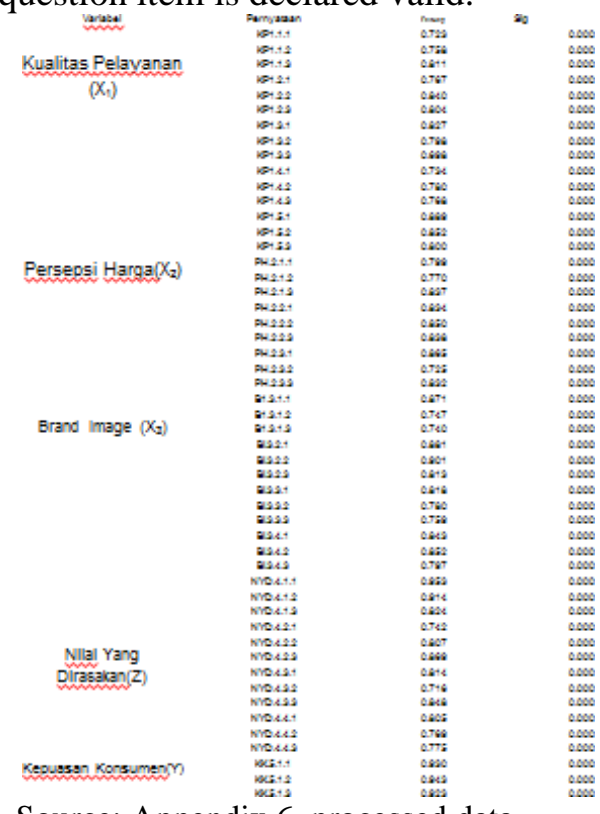

Source: Appendix 6, processed data 
Based on table 4.9 above shows that the results of testing the validity of the statements of all independent and dependent variables are valid, because the sig value is less than 0.05 , so it is stated that all research variables are valid.

\subsubsection{Reliability Test}

The construct reliability test is carried out to measure whether the construct is reliable or not (Ghozali \& Latan, 2012). It is said to be reliable if the Cronbach Alpha is> 0.6. The following are the results of reliability testing:

\section{Reliability Test}

\begin{tabular}{|l|l|l|l|}
\hline Variable & $\begin{array}{l}\text { Cronbach } \\
\text { Alpha }\end{array}$ & Alpha & Conclusion \\
\hline $\begin{array}{l}\text { Service Quality } \\
\text { (KP) }\end{array}$ & 0.956 & 0.6 & Reliable \\
Price Perception & 0.937 & 0.6 & Reliable \\
$\begin{array}{l}\text { PH) } \\
\text { Brand Image (BI) } \\
\text { Perceived Value } \\
\text { (NYD) }\end{array}$ & 0.953 & 0.6 & Reliable \\
$\begin{array}{l}\text { Consumer } \\
\text { Satisfaction (KK) }\end{array}$ & 0.954 & 0.6 & Reliable \\
\hline
\end{tabular}

Source: Appendix 7, Processed Data

Based on Table 4.10 above, it shows that the reliability test results of all indicators of $c$ the independent and dependent variables show reliable, because the Cronbach's Alpha values are all greater than 0.6 , so it is stated that all indicators are reliable.

\subsection{Data analysis}

\subsubsection{Multiple Linear Regression Analysis}

The analysis technique in this study uses multiple linear regression, the results of calculations with the help of the SPSS computer program, obtained the following results:

\section{Sub-Structure Path Equations 1}

Table 4.14

Multiple Linear Regression Analysis of Sub-

Structure Paths 1

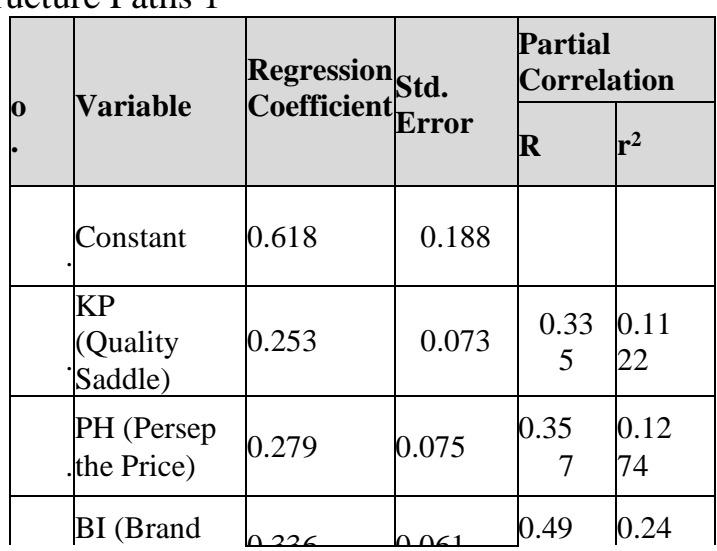

\begin{tabular}{|l|l|l|l|l|}
.Image $)$ & & 0 & 01 \\
\hline
\end{tabular}

Source: Appendix 9, compiled

Based on the table above, the multiple linear regression equation is obtained as follows: $\mathrm{Y}=0.618+0.253 \mathrm{X} 1+0.279 \mathrm{X} 2+0.336 \mathrm{X3}$

From the above equation, it can be explained as follows:

a. The multiple linear regression equation shows the value of $\square$ o (constant) of 0.618 and has a positive value. This value means that if the independent variables Service Quality, Price Perception, and Brand Image are equal to 0 (zero) or constant, then the Perceived Value is 0.618 .

b. Service Quality (KP) regression coefficient $=$ 0.253 . The positive value of the Service Quality regression coefficient indicates a unidirectional relationship to the Perceived Value, meaning that if the Service Quality adds one unit, the Perceived Value will increase by 0.253 . The partial r2 value for the Service Quality variable is 0.1122 , which means that the Service Quality variable is able to explain the Felt Value variable as much as $11.22 \%$.

Price Perception $(\mathrm{PH})$ regression coefficient $=$ 0.279 . The positive value of the Price Perception regression coefficient indicates a unidirectional relationship to the Perceived Value, meaning that if the Perceived Price adds one unit, the Perceived Value will increase by 0.279 . The partial $\mathrm{r} 2$ value for the Price Perception variable is 0.1274 , which means that the Price Perception variable is able to explain the Perceived Value variable for $12.74 \%$.

d. Brand Image $(\mathrm{BI})$ regression coefficient $=$ 0.336 . The positive Brand Image regression coefficient value indicates a unidirectional relationship to the Perceived Value, meaning that if the Brand Image is added one unit then the Perceived Value will increase by 0.336 . The partial $r 2$ value for the Brand Image variable is 0.2401 , which means that the Brand Image variable is able to explain the perceived value variable of $24.01 \%$.

Sub-Structure Path Equations 2 Multiple Linear Regression Analysis of Sub-Structure Path 2

\begin{tabular}{|c|c|c|c|c|c|}
\hline \multirow{2}{*}{$\mathbf{0}$} & \multirow{2}{*}{ Variable } & \multirow{2}{*}{$\begin{array}{l}\text { Regressi } \\
\text { on } \\
\text { Coefficie } \\
\text { nt }\end{array}$} & \multirow{2}{*}{$\begin{array}{l}\text { Std. } \\
\text { Error }\end{array}$} & \multicolumn{2}{|c|}{$\begin{array}{l}\text { Partial } \\
\text { Correlation }\end{array}$} \\
\hline & & & & $\mathbf{R}$ & $\mathbf{r}^{2}$ \\
\hline
\end{tabular}




\begin{tabular}{|l|l|c|c|c|c|}
\hline \hline & Constant & 0.022 & 0.300 & & \\
\hline & $\begin{array}{l}\text { KP } \\
\text { (Service } \\
\text { quality } \\
\text { (l) }\end{array}$ & 0.323 & 0.116 & $\begin{array}{c}0.27 \\
4\end{array}$ & $\begin{array}{c}0.075 \\
1\end{array}$ \\
\hline $\begin{array}{l}\text { PH } \\
\text { Price } \\
\text { Perception) }\end{array}$ & 0.283 & 0.120 & $\begin{array}{c}0.23 \\
5\end{array}$ & $\begin{array}{c}0.055 \\
2\end{array}$ \\
\hline $\begin{array}{l}\text { BI (Brand } \\
\text { Image) }\end{array}$ & 0.094 & 0.106 & $\begin{array}{c}0.09 \\
1\end{array}$ & $\begin{array}{c}0.008 \\
3\end{array}$ \\
\hline $\begin{array}{l}\text { NYD } \\
\text { Perceived } \\
\text { Value) }\end{array}$ & 0.330 & 0.154 & $\begin{array}{c}0.21 \\
5\end{array}$ & $\begin{array}{c}0.046 \\
2\end{array}$ \\
\hline
\end{tabular}

Source: Appendix 9, compiled

Based on the table above, the multiple linear regression equation is obtained as follows:

$$
\begin{aligned}
& \mathrm{Y}=0.022+0.323 \mathrm{X} 1+0.283 \mathrm{X} 2+0.094 \mathrm{X3} \\
& +
\end{aligned}
$$

\section{$0.330 \mathrm{Z}$}

From the above equation, it can be explained as follows.

1. The multiple linear regression equation shows the value of $\square$ o (constant) of 0.022 and has a positive value. This value means that if the independent variables Service Quality, Price Perception, Brand Image, and Perceived Value are equal to 0 (zero) or constant, then Customer Satisfaction is 0.022 .

2. Service Quality $(\mathrm{KP})$ regression coefficient $=$ 0.323 . The positive regression coefficient value of Service Quality indicates a unidirectional relationship with Customer Satisfaction, meaning that if there is an addition of one unit of Service Quality, Customer Satisfaction will increase by 0.323 . The partial $\mathrm{r} 2$ value for the Service Quality variable is 0.0751, which means that the Service Quality variable is able to explain the Customer Satisfaction variable by $7.51 \%$.

3. Price Perception regression coefficient $(\mathrm{PH})=$ 0.283 . The positive regression coefficient value of Price Perception indicates a unidirectional relationship with Customer Satisfaction, meaning that if the Price Perception is an addition of one unit, Customer Satisfaction will increase amounting to 0.283 . The partial $\mathrm{r} 2$ value for the Price Perception variable is 0.0552 , which means that the Price Perception variable is able to explain the Consumer Satisfaction variable by $5.52 \%$.

4. Brand Image $(\mathrm{BI})$ regression coefficient $=$ 0.094. The positive regression coefficient of Brand Image indicates a unidirectional relationship with Customer Satisfaction, meaning that if the Brand Image is added one unit then Customer Satisfaction will increase by 0.094. The partial $\mathrm{r} 2$ value for the Brand Image variable is 0.0083 , which means that the Brand Image variable is able to explain the Consumer Satisfaction variable by $0.83 \%$.

5. Perceived Value (NYD) regression coefficient $=0.330$. The value of the regression coefficient: Positive Perceived Value indicates a unidirectional relationship with Customer Satisfaction, meaning that if the Perceived Value is added by one unit, Customer Satisfaction will increase by 0.330 . The partial r2 value for the Brand Image variable is 0.0462, which means that the Perceived Value variable is able to explain the Consumer Satisfaction variable by $4.62 \%$.

\section{Hypothesis testing \\ Partial Test (t test)}

To determine the effect of each independent variable partially or individually on the dependent variable, $\mathrm{t}$ test analysis is used.

Results of Partial Relationship Variance

\begin{tabular}{|c|c|c|c|}
\hline Testing & Variable & $\mathbf{T}$ & Sig. \\
\hline \multirow{3}{*}{$\begin{array}{l}\text { Pathwa } \\
\text { ys of } \\
\text { ub- ur } \\
\text { structur } \\
\text { e } 1\end{array}$} & $\begin{array}{l}\text { Service Quality } \rightarrow \\
\text { Perceived Value }\end{array}$ & 3,489 & 0.001 \\
\hline & $\begin{array}{l}\text { Perceived Price } \rightarrow \\
\text { Perceived Value }\end{array}$ & 3,740 & 0.000 \\
\hline & $\begin{array}{l}\text { Brand Image } \rightarrow \\
\text { Perceived Value }\end{array}$ & 5,505 & 0.000 \\
\hline \multirow{4}{*}{$\begin{array}{l}\text { Pathwa } \\
\text { ys of } \\
\text { ub- ur } \\
\text { structur } \\
\text { e } 2\end{array}$} & $\begin{array}{l}\text { Service Quality } \rightarrow \\
\text { Customer Satisfaction } \\
\end{array}$ & 2,782 & 0.007 \\
\hline & $\begin{array}{l}\text { Price Perception } \rightarrow \\
\text { Consumer } \\
\text { Satisfaction }\end{array}$ & 2,354 & 0.021 \\
\hline & $\begin{array}{l}\text { Brand Image } \rightarrow \\
\text { Customer Satisfaction }\end{array}$ & 0.888 & 0.377 \\
\hline & $\begin{array}{l}\text { Perceived Value } \rightarrow \\
\text { Customer Satisfaction }\end{array}$ & 2,147 & 0.034 \\
\hline
\end{tabular}
Analysis

Source: Appendix 9, compiled

a. Influence partially Service Quality on Perceived Value

b. Based on calculation with using SPSS obtained a significant level value of 0.001 , where the significant level is smaller than the alpha level of 0.05 , so it can be concluded that the Service Quality variable partially has a significant effect on the Perceived Value.

c. Effect partially on Perceived Price on 
Perceived Value

Based on calculation with using SPSS obtained a significant level value of 0.000 , where the significant level is smaller than the alpha level of 0.05 , so it can be concluded that the Price Perception variable partially has a significant effect on the Perceived Value.

d. Partial Influence of Brand Image on Perceived Value

Based on calculation with using SPSS obtained a significant level value of 0.000 , where the significant level is smaller than the alpha level of 0.05 , so it can be concluded that the Brand Image variable partially has a significant effect on the Perceived Value.

e. Influence partially Service Quality on Customer Satisfaction

Based on calculation with Using SPSS, it was obtained a significant level value of 0.007 , where the significant level is smaller than the alpha level of 0.05 , so it can be concluded that the Service Quality variable partially has a significant effect on Customer Satisfaction.

f. The partial influence of Price Perception on Consumer Satisfaction

Based on calculation with Using SPSS, it was obtained a significant level value of 0.021 , where the significant level is smaller than the alpha level of 0.05 , so it can be concluded that the Price Perception variable partially has a significant effect on Customer Satisfaction.

g. Partial Influence of Brand Image on Customer Satisfaction

Based on calculation with using SPSS obtained a significant level value of 0.377 , where the significant level is greater than the alpha level of 0.05 , so it can be concluded that Brand Image variable partially does not have a significant effect on Customer Satisfaction.

h. Influence partially Perceived Value on Customer Satisfaction

Based on calculation with using SPSS obtained a significant level value of 0.034 , where the significant level is smaller than the alpha level of 0.05 , so it can be concluded that the Perceived Value variable has a significant effect on Customer Satisfaction.

\subsubsection{Simultaneous Test (F Test)}

To determine the relationship or influence of the independent variables simultaneously or as a whole on the dependent variable, the $F$ test is used. In the following table, a simultaneous or overall analysis of the variance of the relationship is presented.

1. Test F Sub-Structure Path 1 Table 4.18

Result of Simultaneous Influence Analysis of Path Sub-Structure 1

ANOVA

\begin{tabular}{|c|c|c|c|c|c|}
\hline Model & $\begin{array}{l}\text { Sum of } \\
\text { Squares }\end{array}$ & $\mathrm{df}$ & Mean Square & $\mathrm{F}$ & Sig. \\
\hline Regression & 5,923 & 3 & 1,974 & 134,033 & $.000^{\mathrm{a}}$ \\
\hline Residual & 1,414 & 96 & .015 & & \\
\hline Total & 7,337 & 99 & & & \\
\hline
\end{tabular}

a. Predictors: (Constant), Brand Image (B1.3), Service Quality (KP1),Price Perception (PH.2)

b. Dependent Variable: Perceived Value (NYD.4)

Based on calculations using SPSS, a significant level of 0.000 is obtained, where the significant level is less than the alpha level of 0.05 , so that the variables of Service Quality, Price Perception, and Brand Image have a significant effect on the Perceived Value.

2. Test F Sub-Structure Path 2 Table 4.19

Result of Simultaneous Influence Analysis of Path Sub-Structure 2

ANOVA ${ }^{b}$

\begin{tabular}{|c|c|c|c|c|}
\hline Model & $\begin{array}{l}\text { Sum of } \\
\text { Squares }\end{array}$ & df & Mean Square F & Sig. \\
\hline Regression & 7,375 & 4 & $1,84455,085$ & $.000^{\mathrm{a}}$ \\
\hline Residual & 3,180 & 95 & .033 & \\
\hline Total & 10,554 & 99) & & \\
\hline
\end{tabular}

a. Predictors: (Constant), Perceived Value (NYD.4), Service Quality (KPI), Brand Image (B1.3), Perceived Price (PH.2)

b. Dependent Variable: Customer Satisfaction (KK.5)

Based on calculations using SPSS, a significant level of 0.000 is obtained, where the significant level is less than the alpha level of 0.05 , so that the variables of Service Quality, Price Perception, Brand Image, and Perceived Value together have a significant effect on Customer Satisfaction.

\section{CONCLUSION}

Based on the results of research and discusion on research on the influence of service quality, price perception, and brand 
image on perceived value and customer satisfaction, the following conclusions are drawn:

1. Service quality has a significant effect on the perceived value of Dian Husada Hospital in Mojokerto. Thus the research hypothesis "There is a significant effect of service quality on the perceived value of consumers (patients) Dian Husada Hospital in Mojokerto" is proven and accepted.

2. Service quality has a significant effect on customer satisfaction at Dian Husada Hospital in Mojokerto. Thus the research hypothesis "There is a significant effect of service quality on customer satisfaction (Patients) Dian Husada Hospital in Mojokerto" is proven and accepted.

3. Price perceptions have a significant effect on the perceived value of the Dian Husada Hospital in Mojokerto. Thus the research hypothesis "There is a significant effect of perceived price on the perceived value of consumers (Patients) Dian Husada Hospital in Mojokerto" is proven and accepted.

4. Price perception has a significant effect on customer satisfaction at Dian Husada Hospital in Mojokerto. Thus the research hypothesis "There is a significant effect of perceived price on customer satisfaction (Patient) Dian Husada Hospital in Mojokerto" is proven and accepted.

5. Brand Image has a significant effect on the perceived value of the Dian Husada Hospital in Mojokerto. Thus the research hypothesis "There is a significant effect of brand image on the perceived value of consumers (patients) Dian Husada Hospital in Mojokerto" is proven and accepted.

6. Brand Image has no significant effect on consumer satisfaction at Dian Husada Hospital in Mojokerto. Thus the research hypothesis "There is a significant effect of brand image on consumer satisfaction (Patients) Dian Husada Hospital in Mojokerto" is not proven and rejected.

7. Perceived value has a significant effect on customer satisfaction at Dian Husada Hospital in Mojokerto. Thus the research hypothesis "There is a significant effect of perceived value on customer satisfaction (Patient) Dian Husada Hospital in Mojokerto" is proven and accepted.

8. Service quality, price perception, brand image and perceived value simultaneously influence customer satisfaction. Thus the research hypothesis "There is a significant effect of perceived service quality, price, brand image and perceived value simultaneously on customer satisfaction (Patient) Dian Husada Hospital in Mojokerto" is proven and accepted.

\section{REFERENCES}

Alma, B. (2014). Manajemen Pemasaran dan Pemasaran Jasa. Bandung: CV Alfabeta.

Armstrong, \& Kotler. (2015). Marketing an Introducing Prentice Hall twelfth edition. England: Pearson Education, Inc.

Assauri. (2003). Manajemen Pemasaran Jasa (I). Jakarta: PT Gramedia.

Gerson, R. F. (2004). Mengukur kepuasan pelanggan. Jakarta: PPM.

Ghozali, I., \& Latan, H. (2012). Partial Least Square: Konsep, Teknik dan Aplikasi SmartPLS 2.0 M3. Semarang: Badan Penerbit Universitas Diponegoro.

Hanif, M. (2013). Marketing Research: Panduan Bagi Manajer, Pimpinan Perusahaan Organisasi. Jakarta: Elex Media Komputindo.

Hasan, A. (2002). Marketing. Yogyakarta: MedPress.

Istijanto. (2005). Riset sumber daya manusia. Jakarta: PT. Gramedia Pustaka Utama.

Kotler, \& Amstrong. (2001). Prinsip-prinsip pemasaran (12th ed.). Jakarta: Erlangga.

Kotler, \& Keller. (2012). Manajemen Pemasaran (Edisi 12). Jakarta: Erlangga.

Kotler, P., \& Keller, K. L. (2008). Manajemen pemasaran (13th ed.). Jakarta: Erlangga.

Kotler, Philip. (2006). Prinsip-Prinsip Pemasaran Jilid 1. Jakarta: Erlangga.

Kotler, Philip. (1987). Marketing Basics. Jakarta: Intermedia.

Kotler, Philip. (1995). Manajemen Pemasaran Analisa, Perencanaan, Implementasi, dan Kegunaan (8th ed.). Jakarta: Salemba Empat.

Kotler, Philip. (2002). Manajemen Pemasaran, Analisis, Perencanaan, Implementasi dan Kontrol. Bandung: Erlangga.

Kotler, Philip, \& Keller, K. L. (2016). Marketing Management (15th ed.). New Jersey: Pearson Pretice Hall, Inc.

Lovelock, C. H., \& Wirtz, J. (2011). Services Marketing: People, Technology, Strategy. Journal of Services Marketing, 18(5).

Lupiyoadi, R., \& Hamdani, A. (2006). Service Marketing Management. Jakarta: Salemba Empat.

Martianawati. (2009). Analisis Pengaruh Brand Image, Kualitas layanan dan Fasilitas SPBU "Pasti Pas" Terhadap Kepuasan Konsumen Pengguna Kendaraan Bermotor (Studi Kasus pada Mahasiswa Fakultas Ekonomi Universitas Diponegoro Semarang). Universitas Diponegoro. 
Setiadi, N. J. (2003). Perilaku Konsumen: Konsep dan Implikasi Untuk Strategi dan Penelitian Pemasaran. Jakarta: Kencana.

Supriyanto, Y., \& Soesanto, H. (2012). Analisis Pengaruh Kualitas Pelayanan, Harga, dan Fasilitas terhadap Kepuasan Pasien Rawat Jalan di Rumah Sakit Kariadi Semarang. Diponegoro Journal of Management, 1(4).

Sweeney, J., \& Soutar, G. (2001). Consumer Perceived Value: The Development of A Multiple item Scale. Journal of Retailing, $77(2)$.

Tjipto, F., \& Chandra, G. (2005). Service, Citra Wisata, dan Setixfaction. Yogyakarta: Andi Offset.

Tjiptono, F. (2005). Strategi Pemasaran I (II). Yogyakarta: Andi Offset.

Tjiptono, F. (2008). Strategi Pemasaran (3rd ed.). Yogyakarta: ANDI.

Tjiptono, F. (2012). Strategi Pemasaran (III). Yogyakarta: Andi.

Tjiptono, F., \& Chandra, G. (2016). Service, Quality, \& Satisfaction (IV). Yogyakarta: Andi Offset.

Zeithaml, V. A. (1988). Consumer Perceptions of Price, Quality and Value: A Means-End Model and Synthesis of Evidence. Journal of Marketing, 52(3).

Zeithaml, V. A., Bitner, M. J., \& Gremler, D. D. (2010). Services Marketing Strategy. In R. A. Peterson \& R. A. Kerin (Eds.), Wiley International Encyclopedia of Marketing: Marketing Strategy (Vol. 1). Chichester, UK: John Wiley \& Sons. 